\section{Taking advantage of the 2010 population census round to strengthen the global evidence base on the health workforce}

\author{
Neeru Gupta*
}

There is an increasing body of evidence of a strong correlation between the density of trained health workers in a country and improved population health outcomes. Yet many countries lack sufficient numbers and equitable distribution of skilled health workers to deliver essential health interventions, such as immunization and skilled attendance at delivery. The World Health Organization estimates that there are 57 countries, mostly located in sub-Saharan Africa, with crisislevel shortages of doctors, nurses, midwives and other health workers (WHO, 2006). An increasing number of stakeholders including international and national agencies, non-governmental organizations and the general public - have become sensitive to the importance of planning, developing and strengthening the health workforce in order to meet national and global health and development goals, including the healthrelated Millennium Development Goals.

With only five years left until the 2015 deadline to achieve the Millennium Development Goals, 2010 presents a critical opportunity for action to increase investment and support to countries to strengthen their health systems, including their health workforce, to deliver primary health services. Despite the undoubted importance of monitoring the health workforce and impacts on population health outcomes, the empirical evidence to support policy formulation is often fragmented. Many sources can potentially produce information relevant to this issue but remain underused in health research, especially among low- and middleincome countries. Falling into this category are national population censuses.

Population censuses with questions on labour force activity and occupation can be a key source for statistics describing the health workforce, providing a comprehensive snapshot of the stock and distribution of health workers in a country (GUPTA et al., 2003; LAVALLEE, et al., 2009). However there are few (if any) documented experiences of health sector planners, managers and policy-makers capitalizing on this resource to inform decision making. In most cases, ministries of health rely exclusively on administrative data sources such as facility staffing records and registries of professional regulatory bodies. While these sources offer many advantages compared to populationbased sources, including being locally available and generally easy to use among non-specialist audiences, having and using a range of data from different sources can help present a fuller picture and minimize the risk of making decisions based on statistics that are incomplete or biased (ABOUZAHR et al., 2007).

In Brazil, like many other countries, population censuses are conducted about once every ten years. The last census for which data are currently available, conducted in the year 2000, included questions on occupation among household members of age of economic activity. The coding of responses, as mapped to the national classification of occupations, allowed for statistical delineation and analysis of those with a health-related occupation, such as medical doctors, nutritionists and nursing auxiliaries. As in many other countries, the national classification holds as reference the International Standard Classification of Occupations (ISCO).

\footnotetext{
* Demographer, Health Workforce Information and Governance, World Health Organization, Switzerland.
} 
The latest revision to the Brazilian classification of occupations was adopted in 2002, and is known as the CBO2002. Specifically, the CBO2002 was mapped against the 1988 revision of ISCO (MINISTÉRIO DO TRABALHO E EMPREGO, 2010). The classification is essentially structured as a hierarchical framework for the statistical grouping of information on the tasks and duties of jobs according to shared characteristics.

Among the particular characteristics of the Brazilian classification, compared with the international standard, is the delineation of health services managers as a specific unit group (i.e. lowest hierarchical level). Given that census data can be disaggregated at the individual level according to sex, for example, this allows for gender based analysis of the health management workforce - a relatively neglected area of health systems research and policy. Analysis of the 2000 census data reveals that, although women represent some two-thirds $(67.3 \%)$ of health workers in Brazil, they are relatively under-represented in health management occupations (55.8\%). The gender gap is found to be much narrower in neighbouring Argentina, where women represent $67.0 \%$ of all health workers and $64.5 \%$ of health managers (LAVALLEE, et al., 2009).

Such findings echo certain concerns of the World Health Organization's Commission on the Social Determinants of Health, notably that health systems can often reflect or even exacerbate many of the social inequalities they are meant to address and be immune from (GEORGE, 2007). The under-representation of women in managerial and decision-making positions may lead to less attention to and poorer understanding of both the particular features of working conditions that characterize much of women's employment, and the healthcare needs specific to women.

It may be noted that ISCO was recently revised, in 2008, and the new revision includes a dedicated unit group for health services managers (INTERNATIONAL LABOUR ORGANIZATION, 2008). At the international level, it is expected that possibilities for analysis of the health workforce, including the health management workforce, will be strengthened in the current global series of demographic censuses (known as the 2010 round), which will largely be able to exploit the ISCO-2008 revision (HUNTER et al., 2009).

Data collection for the current round of the Brazilian census started on August $1^{\text {st }}$, 2010 (IBGE, 2010). The main objective is to achieve timely and accurate data relevant to the country's policy needs. The exercise again includes questions on occupation among the working population, in line with the strong majority (estimated 94\%) of censuses around the world that collect core information on occupation (UNITED NATIONS STATISTICS DIVISION, 2010). The census therefore represents a rich data source to support health workforce monitoring and analysis, within countries and also from a comparative perspective across countries.

At the same time, an ongoing challenge to ensure optimal use of census data to inform health policy options is the need for continuous dialogue, knowledge sharing and collaboration between demographers and other census specialists on the one hand, and policy makers and other users of data and evidence on the other. This is particularly true in Africa, where the health workforce crisis is probably greatest but also the information base weakest. For the 2010 round, censuses have been undertaken or are being planned in 51 of the continent's 53 countries (compared to only 17 undertaken in the previous 2000 round) (AFRICAN CENTRE FOR STATISTICS, 2008). In this context, Brazilian demographers can be active partners in planning, implementing, supporting and disseminating health workforce analyses based on census data - be it in Brazil, lusophone African countries or elsewhere. Some efforts in this direction are already under way (WHO, 2010). Such contributions can be of vital importance in strengthening the evidence base on health workforce opportunities and constraints to strengthening health systems and improving population health locally and globally. 


\section{References}

ABOUZAHR, C. et al. From data to policy: good practices and cautionary tales. Lancet, n. 369, p.1039-1046, 2007.

AFRICAN CENTRE FOR STATISTICS. Status of implementation of 2010 round of population and housing censuses in Africa. African Statistical Newsletter, v. 2, n. 2, p. 7-9, 2008.

GEORGE, A. Human resources for health: a gender analysis. Background paper prepared for the WHO Commission on Social Determinants of Health, 2007. Available in: $<$ http://www.who.int/social_determinants/ resources/human_resources_for_health_ wgkn_2007.pdf>.

GUPTA, N. et al. Uses of population census data for monitoring geographical imbalance in the health workforce: snapshots from three developing countries. International Journal for Equity in Health, v. 2, n. 11, 2003. Available in: <http://www.equityhealthj.com/ content/2/1/11>

HUNTER, D. et al. Boundaries of the health workforce: definition and classifications of health workers. In: DAL POZ, M. R. et al. (Eds.). Handbook on monitoring and evaluation of human resources for health. With special applications for lowand middle-income countries. Geneva, World Health Organization, 2009. Available in: <http://www.who.int/hrh/resources/ handbook/en/index.html>.

IBGE - Instituto Brasileiro de Geografia e Estatística. Censo 2010. Available in: <http://www.ibge.gov.br/censo2010>.
INTERNATIONAL LABOUR ORGANIZATION. International Standard Classification of Occupations, 2008 Revision. Available in: $<$ http://www.ilo.org/public/english/bureau/ stat/isco/index.htm $>$.

LAVALLEE, R. et al. Use of population census data for gender analysis of the health workforce. In: DAL POZ, M. R. et al. (Eds.). Handbook on monitoring and evaluation of human resources for health. With special applications for low- and middleincome countries. Geneva, World Health Organization, 2009. Available in: <http:// www.who.int/hrh/resources/handbook/en/ index.html $>$.

MINISTÉRIO DO TRABALHO E EMPREGO. CBO - Classificação Brasileira de Ocupações. Available in: <http://www.mtecbo.gov. br/cbosite/pages/informacoesGerais.jsf>.

UNITED NATIONS STATISTICS DIVISION. 2010 World Population and Housing Census Programme. Available in: <http:// unstats.un.org/unsd/demographic/sources/ census/2010_PHC>.

WHO - World Health Organization. Report of the technical workshop on measuring health workforce inequalities from a census. Geneva, 2010. Available in: <http:// www.who.int/hrh/resources/workshop hw inequalities.pdf $>$.

World Health Report 2006 working together for health. Geneva, 2006. Available in: <http://www.who.int/whr/2006/ en/index.html>.

Recebido para publicação em 30/11/2009 Aceito para publicação em 15/03/2010 